\title{
APPLICATION OF THE MORATORIUM OVER THE PAYMENT OF LOANS IN CONNECTION WITH THE COVID-19 PANDEMIC AND ITS IMPACT ON THE NATIONAL SECURITY IN THE REPUBLIC OF BULGARIA
}

\author{
Milen Tomov MARINOV \\ “Neofit Rilski" South-West University, Blagoevgrad, Bulgaria \\ milenmarinov1989@abv.bg
}

\begin{abstract}
The activities of banking institutions regarding crediting are undoubtedly among the most significant sources of free capital for the functioning of the market economy of the EU Member States. Therefore, crediting represents one of the most common forms of business financing and the accomplishment of future investment intentions. This mechanism of the credit portfolio serves an extremely wide range of activities related to the specifics of the respective business. Of course, loans are not only used by legal entities engaged in business activities, but they are also engaged to a large extent in the participation of the individuals in the turnover. The provided Moratorium over the payment of loans in the EU is a particularly important act that seeks to bring stability and predictability to the banking system and the public, both for legal entities engaged in business activities, as well as for individuals who, as a result of the imposed measures to overcome the COVID19 pandemic, cannot carry on with their usual activities. The purpose of the present article is to analyse the effect of the moratorium upon the payment of loans and its significance for ensuring the national security in the Republic of Bulgaria in the context of overcoming the negative effects of the pandemic on the EU and the Bulgarian economy.
\end{abstract}

Keywords: bank loan, bank credit, loan, moratorium

\section{Introduction}

There is no doubt that the pandemic caused by COVID-19 has put our modern society up against one of its greatest challenges, the effect of which extends to all spheres of public life. These events led to unprecedented consequences for the economy of the Republic of Bulgaria / and also worldwide /. The necessary stoppage of the activities of a number of operating enterprises led to the loss of a large number of jobs, which directly affected the solvency of citizens. Despite the legislative measures taken to preserve employment, unemployment in the country has reached very high levels. This in turn has made it impossible for a huge number of citizens and companies to service their financial obligations. These difficulties culminated in those natural persons or legal entities that, in one form or another, have used the bank lending system and are currently servicing their loans.

\section{Main body}

In themselves, banking operations have their roots in antiquity, as the legal framework of bank lending can be found even in Roman law and is dated around the IV century BC [1]. Thus, the institute has undergone a dynamic development, as a result of which there have emerged the bank loans we know today. This activity is among the most important sources of free 
capital, which is why it is one of the most common forms of financing. It is a mechanism that functions in all financial aspects of public life - from the creation, maintenance or preservation of working business models to serving the ordinary household needs of citizens. At the same time, this financing is not a gratuitous act, but requires a gradual return of borrowed capital. Failure to comply with this obligation of borrowers often has rather adverse consequences for them. They can vary from the accrual of additional interest / the so-called "Penalty interest" / to the announcement of early repayment of the entire loan, for example in Bulgaria is regulated in Art. 432 of the Commercial Code. If in the first case we are talking for an increase in the amount of the obligation, which must be paid within the agreed term, then in case of forced early repayment the advantage of the term disappears completely. As a result, the borrower would be placed in a situation where all of the borrowed capital together with the accrued penalty interest and expired contractual interest should be immediately repaid. It is clear that this is an obligation that is clearly impossible for a borrower who has lost the opportunity to pay even the annuity installments of the loan. Such a situation would put a number of companies in bankruptcy and would create a real opportunity for many Bulgarian citizens to lose even their homes. This type of loans in practice is always secured by other property / quite often this would be the borrower's home /, against which the bank has the opportunity to initiate execution proceedings. Apart from that, Art. 133 of the Law on Obligations and Contracts establishes the principle that all property of the debtor serves as a general security for the creditor.

The danger of losing one's source of income, one's home, and even one's social status undoubtedly creates a serious criminal activity risk in order to obtain the necessary financial resources. The variety is huge and it is not limited to crimes committed by citizens. The risk of financial collapse would also stimulate the commission of various official crimes and would also create a favorable environment for corruption crimes. The latter is not accidentally defined by the Supreme Court of Cassation as a phenomenon that has an impact on all spheres of life and directly threatens the state [2].

This danger does not at all encompass the negative consequences that could occur for the state. An event of this nature will inevitably lead to lasting financial losses, as bankruptcies of operating enterprises lead to disastrous consequences for the fiscal system. Along with this, inaction on the part of the state in such a situation would lead to the emergence of a lasting anti-state demonstration in society in the long run. In the context of what has been said, there is hardly any doubt about the importance of the lending system set up by banking institutions for the national security both for the individual countries and at the level of the European Union as well. Therefore, even in a situation of crisis, special attention should be paid to the establishment and implementation of working mechanisms for the preservation of these complex relationships in a way that is as favorable as possible for all parties concerned.

Before proceeding to the analysis of the specific measures taken in the Republic of Bulgaria, it is necessary to clarify the legal need for their adoption. From the point of view of law, legislative measures would be necessary only if the current legal framework does not provide a mechanism for overcoming such an unforeseen and unpredictable situation of crisis.

It is obvious that this case regards the socalled force majeure. The principle of action here is simple, but perfectly effective - a contracting party is not liable for the failure to fulfill his obligations due to force majeure. This is the reason why some authors consider the pandemic as a force 
majeure situation and particularly as a force majeure in the field of crediting [3] [4]. Such an analysis has its legal and life logic, but in the Republic of Bulgaria this logic cannot be shared in view of the current legislation. In fact, Art. 81, para. 1 of the CPA regulates the institute of the impossibility to perform the obligations under the contract for a reason that cannot be blamed on him. According to the doctrine the impossibility of performance is available when the performance cannot be fulfilled by the debtor and by those third parties to whose assistance the debtor could be expected to be able to resort [5]. However, when considering the issue of the faultless impossibility to perform through the prism of the performance of monetary obligations, such as the obligations under the loan agreement, we must comply with the provision of Art. 81, para. 2 of the CPA, according to which the circumstance that the debtor does not have funds to fulfill the obligation does not release him from liability. We are therefore faced with the existence of an explicit legal text which denies the lack of funds as a force majeure circumstance, even if this lack is caused by force majeure. Therefore, in order to overcome the negative consequences of COVID-19 in the field of crediting in the Republic of Bulgaria, it was necessary to adopt specific measures through the legislative initiative.

This happened with the adoption of the Law on Measures and Actions during the State of Emergency, announced by a decision of the National Assembly of March 13, 2020, which was promulgated in the State Gazette on March 24, 2020. The issue was settled sparingly and not precisely with the provision of art. 6 of the aforementioned normative act. The cited provision provided that until the repeal of the state of emergency, the consequences of the delay in payment of debts of private legal entities, including interest and penalties for delay, as well as the non-monetary consequences such as early repayment, cancellation of contract and seizure of property, do not apply. Such measures have been introduced in one form or another in all Member States of the European Union. Here is the moment to note that according to Art. 3 of the Treaty on the Functioning of the European Union, in the field of monetary policy of the Member States the EU has the exclusive legislative competence. In this particular case, the report of April 02, 2020 of the European Banking Authority (EBA) is of great practical importance, in which there were given methodological guidelines to the Member States regarding the legislative and non-legislative measures for overcoming the consequences of COVID19 in the field of crediting [6]. This act contains the obligation of Member States to comply with the given instructions or to inform the EBA about the reasons for their non-application. As a result of the so published report, the commented provision of Art. 6 was specified and amended in the following sense: "Art. 6. Until the repeal of the state of emergency, in case of delay in payment of obligations of private legal entities, that are debtors under credit agreements and other forms of financing (factoring, forfeiting, etc.), provided by banks and financial institutions under Art. 3 of the Credit Institutions Act, including when the receivables have been acquired by other banks, financial institutions or third parties, and under lease agreements, interest for delay and penalties are not charged, the obligation cannot be declared prematurely due and the contract cannot to be cancelled due to non-performance, and no items can be seized."At the moment these are the current legislative measures concerning crediting in the context of the COVID-19 pandemic.

It is no coincidence that in its guidelines, the EBA draws attention to the need to adopt a package of measures, including such of non-legislative nature. Such measures were taken in the Republic of Bulgaria as well, and on the basis of a Decision of the Council of Ministers No. 
257 / 14.04.2020 there was created the Program for guaranteeing interest-free loans in assistance to people deprived of the opportunity to work due to the pandemic of COVID-19.

The implementation of this type of measures was assigned to the Bulgarian Development Bank. In practice, a tool was created, which provided individuals with the opportunity to obtain interest-free and unsecured loans of up to BGN 4,500 /approximately $2300 \mathrm{EUR} /$. There was also a long maximum repayment period - 5 years, with a minimum of 6 months and a maximum of 24 months grace period. In this way, a mechanism was created that could be used for a kind of refinancing of loans to individuals, and the latter could use this interest-free loan not only to cover their current expenses, but also to repay due installments of their bank loans. In addition, operational programs have been introduced to support small and medium-sized businesses through the provision of such loans. These measures are a clear expression of European solidarity and are currently under discussion and expanding their scope.

This type of measures should be highly praised - they are effective and provide the necessary financial resources to those, who are most affected by the crisis, while not leading to financial losses to the state.

In addition, special attention (as well as a positive assessment) deserve the quick steps taken in the direction of the application of the Republic of Bulgaria for membership in the Eurozone. Thus, as early as April, 2020, the Republic of Bulgaria began the preparations for the deposit of the necessary documents for entry into the ERM II exchange rate mechanism - the so-called waiting room of the Eurozone. This procedure was started at the beginning of the year, but as a result of serious public discussions, its progress was delayed. However, the government's approach in the crisis situation to take decisive action in this direction was correct. These actions also gave rise to high results - the conclusion of the currency protection agreement / swap line / between the Bulgarian National Bank and the European Central Bank. The latter, in turn, provides the necessary liquidity in the adoption of the Euro currency, which is new for Bulgaria.

From the point of view of legislative measures, however, we can rightly demand more. The provision adopted in that regard is not in a position to fully achieve its objective. This provision provides sufficient protection for citizens, but also brings up a number of issues. In this connection, we should first pay attention to the fact that the legislator intended for the measures to apply "until the state of emergency is repealed". In practice, this means that the consequences of the delay would take effect immediately since the first day on which the state of emergency has been repealed. Under the now active legislation, as of this moment credit debtors will have to pay all accumulated installments immediately under fear of accumulating penalty interest or even declaring early repayment. This text should be revised by the legislator before the practice faces the potential problems it may lead to.

Next, it is clear that, for one reason or another, the legislature has decided not to adopt paragraphs 17 and 26 of the guidelines given in the EBA report. In paragraph 17, the EBA points out that the moratorium on payments will be widely applied, which is why its conditions must be settled in detail and provide a flexible approach in different cases. The logic behind these guidelines is clear - the need for a differentiated approach to borrowers whose situation has remained unaffected by the pandemic. It is unnecessary, illogical and even harmful to treat as equal all debtors under bank loan agreements. However, this is exactly what was done with the provision of Art. 6 of the Measures and Actions during the State of Emergency Law, declared by a decision of the National Assembly of March 13, 2020. The cited 
legal text in practice imposed a moratorium on payments of all loans, including those under which debtors are fully solvent. Of course, the pandemic created an unfavorable economic situation for most participants in the civil and commercial turnover. However, this does not change the fact that there are many unaffected individuals and legal entities, and there are certain sectors / such as pharmacy and the production of protective equipment / that are even booming. It is clear that this category of legal entities does not need the protection provided by the moratorium on payments. In practice, this protection puts those unaffected by the pandemic in a more favorable position than the one they were in before it arose. On the one hand, they are unaffected or even benefited from the crisis situation, and on the other hand, they receive additional financial relief, giving them the opportunity to defer payments on their loans. And this is at the expense of the banking system, which is unable to realize the most part of its income. It is in this context that the EBA report repeatedly raises the issue of the risk assessment and the need to address the problem and the stability of the banking system. The idea behind the Moratorium is not to stop banking, but to give a respite to the borrowers who need it. Instead, the legislator has "frozen" all loans, which creates an obstacle for banking institutions to receive their income and collect their receivables from debtors whose assets allow for smooth servicing of loans. In the long run, this would create a risk of lack of liquidity, which is a separate risk for the stability of the banking system, and hence for the national security, which is why this legislative approach cannot be approved.

With regard to item 27 of the report, the decision of the legislator not to comply with it is justified in view of the acting legislation in the Republic of Bulgaria. The cited part of the report examines the need for the moratorium on payments to be applied only in relation to the problems caused directly by the COVID-19 pandemic. As an example, the moratorium should not apply to new loans granted after its adoption. However, the legislator did not envisage such a restriction in the application of the moratorium, which is the right approach, as it would deny the possibility of refinancing current loans. It should not be forgotten that the lending activity is carried out by commercial banks, which participate in the turnover as independent legal entities and have the right to decide whether to provide their client with a new loan under a moratorium on payments. There is no logical reason for this activity to be legally restricted and to deprive credit institutions of the opportunity to develop their activity. The credit institution concerned shall have the right to autonomously assess whether such a transaction is economically viable. The latter could also bring financial benefits to the credit institution concerned - for example, it could serve as a means of attracting new customers or negotiating more favorable terms for the bank.

On the other hand, the fact that the legislator has not differentiated the delay in the credits depending on whether it precedes the state of emergency in time or not, deserves praise. At first sight, it would be logical for the moratorium to apply only to payments that are due and have remained outstanding in the context of a pandemic, and not to the arrears that precede it. But that would be wrong. To adopt this approach would mean to enable credit institutions to declare early repayment of a loan during a crisis situation if there are overdue installments that occurred before it did. However, according to the Bulgarian legislation, as it was emphasized in Interpretative Decision No. 4 of 18.06.2014 under Interpret. d. No. 4/2013 of the Supreme Court of Cassation - the preliminary repayment of the loan cannot occur automatically, but there needs to be a deliberate statement by the bank under Art. 60 , para. 2 of the LCI. The practice has 
required this statement to be accompanied by an invitation for execution of the overdue installments, and in case of their non-fulfillment, the loan shall be considered as pre-term due. However, in a pandemic, this procedure would be of a formal nature, as the borrower affected by the crisis will clearly not be able to meet the due installments. In those circumstances, the borrower would be virtually deprived of the possibility of avoiding the declaration of early repayment. It is this possibility that is protected by the prohibition on banking institutions to apply the effects of late payment, whether or not the delay had occurred before the state of emergency was declared.

\section{Conclusion}

In conclusion, with some critical remarks, we can give a positive summary assessment of the legislative and non-legislative measures taken to deal with the consequences of the COVID-19 pandemic. Although there is still much to be desired from the legislative actions taken, we must not forget that we are talking about actions taken as a matter of urgency and in a state of severe crisis, which in the end adequately fulfill the main purpose of the moratorium on credit payments. However, it is necessary to overcome the current limited timeframe of the measures, as they deal with the effects of COVID-19 in the time of the duration of the state of emergency and several months thereafter. A more comprehensive approach would be more appropriate here, in order to create a mechanism that would always operate in situations of crisis, so that, in the event of such protection being needed in the future, the entities concerned can obtain it immediately, on the basis of legislative measures preceding it and already tested at another time of crisis.

\section{References}

[1] Heichelheiun, F. M. Romanische Social-und Weidmanische Buchhandlung, 1987.

[2] Decision № 190 of 29.11.2018 under n.d. № 802/2018 of the Supreme Court of Cassation, 1st dec. department.

[3] "COVID-19: FORCE MAJEURE EVENT?", published on https://www.shearman.com/perspectives/2020/03/covid-19--force-majeure-event

[4] THE COVID-19 CRISIS AND FORCE MAJEURE IN CREDIT AGREEMENTS, published on https://www.shearman.com/perspectives/2020/03/the-covid-19-crisis-andforce-majeure-in-credit-agreements.

[5] Kalaydzhiev, A. Obligation law. General part, p. 271, 2002.

[6] Guide lines on legislative and non-legislative moratoria on loan repayments applied in the light of the COVID-19 crisis. Published on https://eba.europa.eu/regulation-andpolicy/credit-risk/guidelines-legislative-and-non-legislative-moratoria-loan-repaymentsapplied-light-covid-19-crisis. 